\title{
Marine biodiversity of Gulf of Kutch located in North-eastern Arabian Sea
}

\begin{abstract}
Marine biodiversity depends of many factors viz. sediment quality, water quality, tidal waves, tidal amplitude, intertidal zone influence, depth of sea, bottom topography, etc. Here, we have analyzed for these factors to assess the impact on marine biodiversity especially benthos and planktonic organisms. The study of Gulf of Kutch shows that the area is rich in coral reef and benthos; it should not be disturbed in any case for commercial or any other uses.
\end{abstract}

Keywords: marine biodiversity, arabian sea, gulf of kutch, corals
Special Issue - 2018

\author{
Ashok K Rathoure \\ Ecology \& Biodiversity Expert, Ecosystem Resource \\ Management Pvt. Ltd. India
}

Correspondence: Ashok K Rathoure C/O Mr. Gyanendra K. Rathoure, Mayashivraj Sadan, Gupta Colony, Hardoi-24I00I, UP, India, Phone +91 945050 |47।, Email asokumr@gmail.com

Received: July 13, 2018 | Published: August 01, 2018

\section{Introduction}

The Gulf of Kutch is opening towards the north-eastern Arabian Sea. The channel depths is varying from $20 \mathrm{~m}$ at the head to $60 \mathrm{~m}$ in central areas of the outer Gulf. Though water depths of $25 \mathrm{~m}$ exist in the broad central portion of Gulf up to a longitude $70^{\circ} \mathrm{E}$, the actual fairway is obstructed by the presence of several fish flocks. The high tidal influx covers the low lying area of about $1500 \mathrm{~km}^{2}$ comprising networks of creeks and alluvial marshy tidal flats in the interior region. The creek system consists of three main creeks namely Nakti, Kandla and Hansthal and little Gulf of Kutch interconnecting through many other big and small creeks. All along the coast, very few rivers drain into the Gulf of Kutch and they carry only a small quantity of freshwater, except during brief monsoon. The southern shore of the Gulf has abundant islands and inlets covered with mangroves and surrounded by coral reefs. The northern shore is mostly sandy or muddy provoked by several fish flocks.

\section{Physiological conditions}

The Gulf has mixed and predominantly semidiurnal type tides with a large diurnal inequality. This is because of complex bathymetry, rough bottom topography and undulation in the shoreline which produce highly non-linear tidal interactions. The tidal waves are entering from the west side and the tidal amplitude increases considerably in the upstream of Vadinar due to shallow inner regions and narrowing cross-section. The tidal elevations (m) are as follows: (Table 1).

Table I Tidal elevations $(\mathrm{m})$ in gulf of kutch

\begin{tabular}{llllll}
\hline Location & MHWS & MHWN & MLWN & MLWS & MSL \\
\hline Okha & 3.47 & 2.96 & 1.20 & 0.41 & 2.0 \\
Sikka & 5.38 & 4.35 & 1.74 & 0.71 & 3.0 \\
Rozi & 5.87 & 5.40 & 1.89 & 1.0 & 3.6 \\
Kandla & 6.66 & 5.17 & 1.81 & 0.78 & 3.9 \\
Navlakhi & 7.21 & 6.16 & 2.14 & 0.78 & 4.2 \\
\hline
\end{tabular}

MHWS = Mean high water springs; $M$ HWN = Mean high water neaps; $M L W N=$ Mean Low Water Neap; MLWS= Mean low water springs; MSL= Mean Sea level

Over the stretch of the Gulf, the mean spring tidal range increases impressively from $3.47 \mathrm{~m}$ at Okha to $7.21 \mathrm{~m}$ at Navlakhi. The phase lag between Okha and Kandla is $2 \mathrm{~h}$ to $2 \mathrm{~h} 25$ min while between Okha and Navlakhi it is $3 \mathrm{~h}$ to $3 \mathrm{~h} 20 \mathrm{~min}$. Due to high tidal ranges in the inner regions, the vast mudflats and coastal low lands which get submerged during high tide are fully exposed during low tide (Figure $1){ }^{1}$

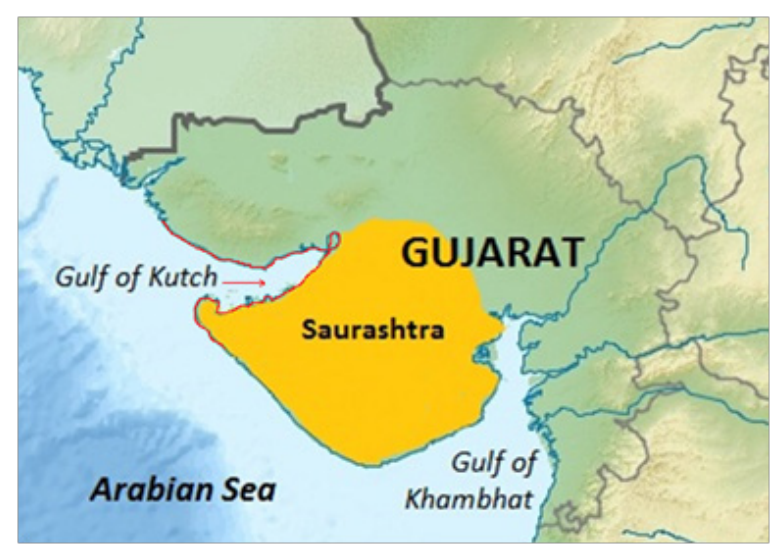

Figure I Map of Gulf of Kutch.

The tidal circulation is principally controlled by the tidal flows and bathymetry though wind effect also conquers to certain magnitude. The surfaces currents are moderate $(0.7-1.2 \mathrm{~m} / \mathrm{s})$ but increase considerably $(2.0-2.5 \mathrm{~m} / \mathrm{s})$ in the central portion of the Gulf. The spring currents are 60 to $65 \%$ stronger than the neap streams. The bottom currents are also periodic with a velocity normally $70 \%$ of the surface streams.

\section{Water quality}

The yearly deviation of water temperature is between $20^{\circ} \mathrm{C}$ and $30^{\circ} \mathrm{C}$, although the localized higher temperature goes upto $35^{\circ} \mathrm{C}$ which can result in isolated water pools formed in shallow intertidal depressions during low tide. Vertical profiles of temperature and salinity reveal a nearly homogeneous water column with no vertical stratification due to intense tidal-driven turbulence mixing.

The suspended solids (SS) are highly variable, spatially and largely resulted from the dispersion of fine sediment from the bed and the intertidal mudflats due to tidal movements. Obviously, near shore shallow region, invariably sustain higher suspended solids as compared to the central zones. The region between Okha and Sikka has high variable suspended solids $(4-308 \mathrm{mg} / \mathrm{L})$ whereas the inner Gulf areas sustain markedly higher suspended solids, even up to 
$700 \mathrm{mg} / \mathrm{L}$. The $\mathrm{pH}$ range of the Gulf water is remarkably constant (8.0-8.3) though wide variations (7.6-8.8) are not iced sometimes. The evaporation exceeds precipitation leading to salinities markedly higher than that of the typical seawater. This is particularly evident in the inner Gulf where salinities as high as 40 psu commonly occur off Kandla and Navlakhi. Although the salinities decrease considerably for a brief period in some creeks of the Little Gulf of Kutch under the influence of monsoonal runoff, the 20 impact of this decrease in the Gulf proper is small and salinities often exceed 36 psu at most of the locations. ${ }^{2-3}$

The average DO is fairly high ( $35 \mathrm{mg} / \mathrm{L})$ most of the times and the BOD is low $(<0.1-6.3 \mathrm{mg} / \mathrm{L})$ indicating good oxidizing conditions. The nutrients $\left(\mathrm{PO}_{4}^{3-}-\mathrm{P}, \mathrm{NO}_{3}-\mathrm{N}, \mathrm{NO}_{2}-\mathrm{N}, \mathrm{NH}_{4}{ }^{+}-\mathrm{N}\right)$ are more or less uniformly distributed in the Okha-Sikka-Mundra segment and their concentrations indicate healthy natural waters. Their levels are marginally high in the Kandla-Navlakhi segment. Actually, the network of creeks of the Little Gulf of Kutch sustains high natural concentrations of nutrients perhaps due to high regeneration rates.

\section{Sediment quality}

The central part of the Gulf of Kutch is rocky with sediments limited to the boundaries. The sediment near shore which consists of light gray silt, clay and fine sand with patches of coarse sand inbetween, are poorly arranged with highly variable skewness. The major source of this sediment is considered to be the shore material and the load transported by the Indus River. The portion of sediment derived from the hinterland is considered to be small because of the low run-off. Furthermore, the streams discharging in the Gulf of Kutch are short with dams constructed on many of them. ${ }^{4}$

\section{Methodology}

The methodology and parameter adopted for this study mentioned in Table 2 below. ${ }^{5-16}$

Table 2 Mode of Data Collection and Parameters for Marine life

\section{Aspect Mode of data collection $\quad$ Parameters monitored Remarks}

- Guidelines of APHA for water sample collection

- Physical/virtual identification at site/direct sighting of fresh water or marine life.

Marine
- Confirmation from fisherman, local villagers, professionals, etc.

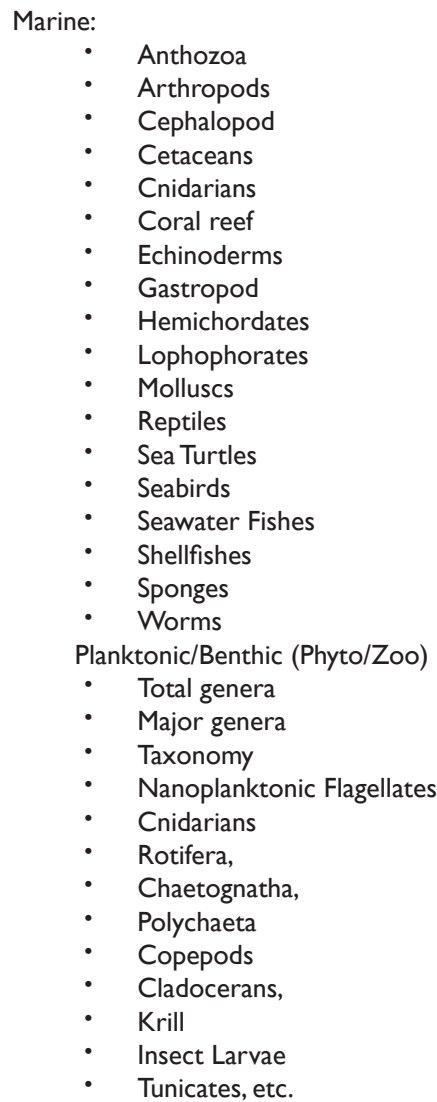

Endangered, threatened and the most common fresh water and marine species.

By using Lackey's drops method and light microscope

Physical/virtual identification

Verification by authentic agency (BSI, ZSI,

FRI, NIO, etc.) 


\section{Sampling locations}

The sampling locations for marine biodiversity assessment are given in Table 3.

Table 3 sampling locations for marine biodiversity

\begin{tabular}{llllll}
\hline SNo & Locations & Code & SNo & Locations & Code \\
\hline I & Okha & MBI & 9 & Ajad & MB9 \\
2 & Dholio Gugar & MB2 & 10 & Bural reef & MBI0 \\
3 & Dona & MB3 & II & Dhani & MBII \\
4 & Boria & MB4 & I2 & Kalumbhar reef & MBI2 \\
5 & Mangunda & MB5 & I3 & Narara reef & MBI3 \\
6 & Savaj & MB6 & I4 & Goose reef & MBI4 \\
7 & Paga & MB7 & I5 & Pirotan island & MBI5 \\
8 & Manmarudi & MB8 & - & - & -
\end{tabular}

\section{Results and discussion}

The Gulf of Kutch flourishes in marine wealth and is considered as one of the biologically richest marine habitat along the west coast of India. The marine flora is highly varied and includes sand dune vegetation, mangroves, sea grasses, macrophytes and phytoplankton. In all 31 species of Chlorophyceae, 33 species of Phaeophyceae and 55 species of Rhodophyceae have been identified with the dominance of Phaeophyceae. The dominant species of sand dune flora are Euphorbia caducifolia, E.neriifolia, Aloevera sp, Ephedra foliata, Urochodra setulosa, Sporobolus maderaspatenus, Eragrostis unioloides, Calotropis procera, Fimbristylis sp, Indigofera sp and Ipomoea pescaprae. The common sea grasses found growing on the mud flats are Halophila ovata, H.beccarii and Zostrea marina.

The most common marine algal species are Ulva fasciata, U. reticulata, Enteromorpha intenstinalis, Dictyota sp, Hypnea musciformis, Sargassum tennerimum, S.ilicifolium, Gracilaria corticata, Cystocera sp, Padina tetrastomatica, Corallina sp, Laurencia sp, Caulerpa racemosa, Bryopsis sp, Turbinaria sp, Ectocarpus sp, Acanthophora sp, Chondria sp, and Codium sp.

The primary production of the water column as assessed from chlorophyll a concentration is generally high in the outer Gulf but decreases in the inner regions. Phytoplankton represents about 31 genera and 41 species. The major phytoplankton genera are Rhizosolenia, Synedra, Chaetoceros, Navicula, Nitzschia, Pleurosigma, Thalassiothrix, Biddulphia, Stauroneis, Coscinodiscus and Skeletonema. The Gulf also sustains good and variable zooplankton and benthic standing stock with diversity. The primary and secondary tropic levels offer congenial feeding grounds for prawns and fishes in the Gulf.

The intertidal zone of the Gulf of Kutch is rich in biota. Sheltered bays, creeks and mud flats provide ideal sites form mangrove vegetation over an estimated area of about $1066.9 \mathrm{~km}^{2}$. The formations are of open scrubby type, with isolated and discontinuous distribution from Kandla-Navlakhi in the northeast to Jodia, Jamnagar, Sikka, Salaya and Okha in the southwest, as also at Pirotan, Positra, Dohlani and Dwarka. Vast stretches of mangroves also exist along the northern shore of the Gulf. The dominant species of mangroves are
Avicennia marina var acutissima, A. officinalis, Bruguiera parviflora, B. gymnorphiza, Rhizophora mucronata, R. apiculata, Ageiceros corniculata, Ceriops tagal and Sonneratia apetata alongwith the associated species of Salicornia brachiata, Rosella Montana, Suaeda fruticosa, Artiplex stocksii and lichen.

The marine fauna of the Gulf is rich, both in variety and abundance. Sponges having an array of colours are observed, both in the intertidal and subtidal biotopes. The common species of sponge is Adocia sp, associated with coral reef fauna. In sandy and silty mud shores, Tetilla dactyloidea (Carter) is common.

The most frequently encountered hydrozoans are Sertularia $s p$ and Plumularia sp. The giant sea-anemone (Stoichactis giganteum) is a common sight in the coral ecosystem. Sea anemones, belonging to Anemonia, Bunodactis, Paracondylactis, Anthopleura and Metapeachia, are wide spread. Azoantharian, Gemmaria sp, is found forming extensive hexagonal green mats in the coral pools. Another interesting actiniarian is the Cerianthus $s p$ found in tubes in the soft mud. The Gulf has 42 islands, 34 of which have live corals. Siltation is the main cause affecting the coral growth. The species diversity however is poor with identification of 36 species of Scleractinian and 12 species of soft corals. A number of polychaete worms, both sedentaria and errantia, with the dominant genera of Eurythoe, Terebella, Polynoe, Iphione and Nereis are rather common. A mongst a variety of sipunculid and echiuroid worms, the dominant species are Dendrostromum sp, Asphidosiphon $s p$ and Ikadella misakiensis (Ikeda). The intertidal crustacean fauna is very rich and equally diverse with spider crab (Hyas sp) and furry crab (Pillumnus sp), as specialities.

Amongst the invertebrate component of the marine fauna of the Gulf, the molluscs have the highest representatives. As many as 92 species of bivalves, 55 species of gastropods, 3 species of cephalopods and 2 species each of scaphopods and amphineurans have been reported. The most notable members of the molluscan fauna are octopus, pearl oyster and a variety of chanks, including the sacred chank. Pinna bicolar, the bivalve is commonly noticed in the coral reef flat.The echinoderm fauna, represented by 4 classes and 14 genera, have the commonest genera of Palmpsis, Astropecten, Asteria, Temnopleura and Holothuria. The subtidal benthic fauna of the Gulf is dominated by polychaetes, crustaceans, echinoderms, gastropods and bivalves, with an average biomass of $25 \mathrm{~g} / \mathrm{m}^{2}$.

The Gulf of Kutch has a variety of exploitable species of finfishes and shellfishes. The sciaenids, polynemids, perches, eels, cat-fishes, elasmobranchs and prawns are commercially important groups with an average catch of $1.4 \times 10^{5}$ ton/year. The fishing grounds for Ghol, Karkara, Khaga, Dhoma, Magra and Musi exist in the Gulf. The Gulf region offers plenty of facilities for feeding, breeding and shelter to a variety of birds. In the mangrove forests lining the islands and along the coast, the birds find a near perfect environment. In addition, they are well placed to reach their food supply i.e. the shoals of fish, squids, mud skippers and other animals, during low tide. All along the creeks and around islands, mangrove trees and mudflats are seen crowded with Grey Herons, Pond Herons, Painted Storks, Large and small Egrets, Darters, Cormorants, Flamingos, Lesser Flamingos, etc. during the period of seasonal migration (November-March). ${ }^{17}$

The large congregations of uncommon coastal waders such as Bartailed Godwit (Limosa lapponica), Sanderling (Calidris alba), Large Sand Plover (Charadrius leschenaultii), Eurasian Curlew (Numenius 
arquata), Eurasian Oystercatcher (Haemotopus ostralegus) and Crab Plover (Dromas ardeola) occur only in the Gulf. As per the Bird Life International Red Data List and IUCN 2002 Red Data Book, the MNP is home to several globally threatened species, such as Spot-billed Pelican (Pelecanus philippensis), Dalmatian Pelican (P. crispus), Greater Spotted Eagle (Aquila clanga), Indian Skimmer (Rhynchops albicollis), Black-necked Stork (Ephippiorhynchus asiaticus) and Pallas's Fishing Eagle (Paliaeetus leucoryphus). The Gulf region is also important for marine turtles and sea mammals. ${ }^{17}$

Though a detailed systematic survey of biota is lacking, following number of species have been reported: (Table 4)

Table 4 Number of marine species

\begin{tabular}{ll}
\hline Flora/fauna & Species (Nos.) \\
Algae & 130 \\
Molluscs & 200 \\
Sponges & 70 \\
Crabs & 30 \\
Corals & 36 \\
Birds & 200 \\
Fishes & 200 \\
Sea mammals & 3 \\
Sharks & 8 \\
Sea turtles & 3 \\
Prawns & 27 \\
\hline
\end{tabular}

Because of its high bio-geographical importance and rich flora and fauna, several areas along the southern Gulf are notified under the Marine National Park (16,289 ha.) and the Marine Sanctuary $(29,503$ ha.) (Figure 2).

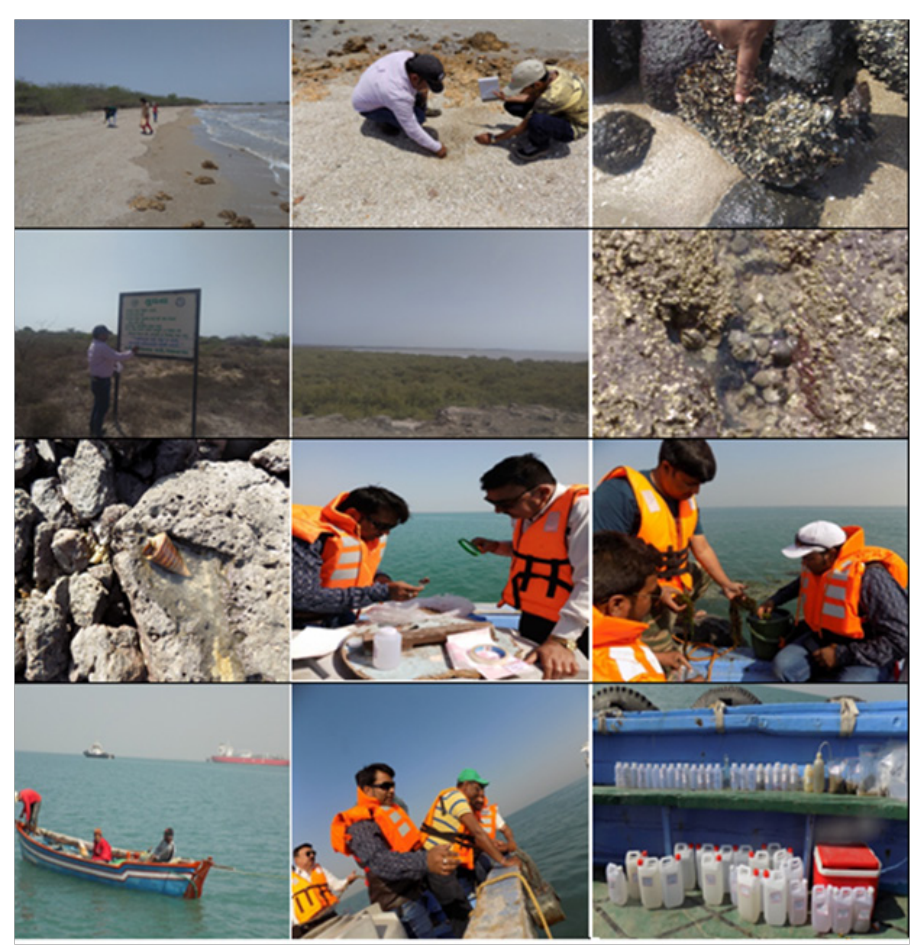

Figure 2 Marine sampling.

Table 5 List of intertidal algae of the Gulf

\begin{tabular}{|c|c|c|c|c|c|}
\hline Name & Status* & Name & Status* & Name & Status* \\
\hline Chlorophyceae & & Phaeophyceae & & Rhodophyceae & \\
\hline Boodlea composita & C & Colpomenia sinuosa & C & Acanthophora delilei & C \\
\hline Bryopsis indica & C & Cystoceira indica & C & A. specifera & $\mathrm{R}$ \\
\hline B. plumose & C & Dictyota atomaria & C & Amphiroa fragilissima & $\mathrm{R}$ \\
\hline B. ramulosa & C & D. bartayrisiana & $\mathrm{R}$ & Asparogopsis taxiformis & C \\
\hline Caulerpa crassifolia & C & D. cervicornis & $\mathrm{R}$ & Botroycladia leptapoda & C \\
\hline C. cupressoides & C & D. ciliolate & C & Calaglossa bombayance & $\mathrm{R}$ \\
\hline C. racemosa & C & D. dichotoma & C & Ceramium sp. & C \\
\hline C. scalpelliformis & C & D. divaricata & $\mathrm{R}$ & Champia indica & C \\
\hline C. sertularioides & C & Dictyopteris australis & C & Chondria ornata & $\mathrm{R}$ \\
\hline C. verticillata & C & Ectocarpus sp. & C & Coelarthrum opuntia & C \\
\hline Chaetomorpha indica & C & Hinskia mitchelle & C & Corallina officinalis & C \\
\hline Chamaedoris auirculata & C & Hormophysa triquetra & $\mathrm{R}$ & Corynomorpha prismatica & $\mathrm{R}$ \\
\hline Cladophora glomerata & C & Hydroclathrus clathratus & $\mathrm{R}$ & Cryptopleur sp. & $\mathrm{R}$ \\
\hline C. prolifera & C & lyengaria stellata & C & Dasya sp. & $\mathrm{R}$ \\
\hline Codium decorticatum & $\mathrm{R}$ & Myriogloea sciurus & $\mathrm{R}$ & Desmia hornmanni & $\mathrm{R}$ \\
\hline C. dwarkensis & C & Nemacystus decipiens & $\mathrm{R}$ & Gastroclonium iyengarii & $\mathrm{R}$ \\
\hline
\end{tabular}


Table Continued

\begin{tabular}{|c|c|c|c|c|c|}
\hline Name & Status* & Name & Status* & Name & Status* \\
\hline C. elongatum & C & Padina gymnospora & $\mathrm{R}$ & Galaxaura oblongata & C \\
\hline Dictyosphaeria cavernosa & $\mathrm{C}$ & P. tetrastromatica & C & Gelidiella acerosa & C \\
\hline Enteromorpha intenstinalis & C & Pocockiella sp. & C & Gelidiospsis gracilis & C \\
\hline Halideda tuna & C & Rosenvingia intricata & $\mathrm{R}$ & Gigartina sp & $\mathrm{R}$ \\
\hline Pseudobryopsis mucronata & $\mathrm{R}$ & Sargassum johnstonii & C & Gracilaria corticata & $\mathrm{R}$ \\
\hline Spongomorpha sp. & C & S. tenerrimum & C & G. pygmaea & C \\
\hline Udoea indica & $\mathrm{C}$ & S. plagiophyllum & $\mathrm{R}$ & Gastroclonium iyengarii & $\mathrm{R}$ \\
\hline Ulva fasciata & C & S. swartzii & C & Galaxaura oblongata & C \\
\hline U. lactuca & C & S. wisghtii & $\mathrm{R}$ & Gelidiella acerosa & C \\
\hline U. reticulata & $\mathrm{R}$ & Spathoglossum asperum & $\mathrm{R}$ & Valonia utricularis & $R$ \\
\hline Valonia utricularis & $\mathrm{R}$ & S. variabile & C & Valloniopsis spachynema & $\mathrm{R}$ \\
\hline Valloniopsis spachynema & $\mathrm{R}$ & Gelidiospsis gracilis & C & - & - \\
\hline Stoechospermum marginatum & $\mathrm{C}$ & Gigartina sp & $\mathrm{R}$ & - & - \\
\hline Spathoglossum asperum & $\mathrm{R}$ & Gracilaria corticata & $\mathrm{R}$ & - & - \\
\hline S. variabile & C & G. pygmaea & C & - & - \\
\hline Stoechospermum marginatum & C & G. verrucossa & $\mathrm{R}$ & - & - \\
\hline Turbinaria ornata & $\mathrm{R}$ & Grateloupia inica & C & - & - \\
\hline- & - & G. felicina & $\mathrm{R}$ & - & - \\
\hline - & - & Haloplegma sp. & $\mathrm{R}$ & - & - \\
\hline- & - & Halymenia floresia & $\mathrm{R}$ & - & - \\
\hline - & - & H. porphyroides & C & - & - \\
\hline- & - & $H$. venusta & C & - & - \\
\hline - & - & Helminthocladia clayadosii & C & - & - \\
\hline - & - & Heterosiphonia muelleri & C & - & - \\
\hline- & - & Hypnea cervicornis & C & - & - \\
\hline- & - & H. musciformis & C & - & - \\
\hline - & - & Hypoglossum spathulatum & $\mathrm{R}$ & - & - \\
\hline- & - & Laurencia papillosa & C & - & - \\
\hline- & - & L. pedicularioides & C & - & - \\
\hline- & - & Liagora cerenoides & $\mathrm{R}$ & - & - \\
\hline- & - & Lophocladia lallemandi & $\mathrm{R}$ & - & - \\
\hline - & - & Neurymenia fraxinifolia & $\mathrm{R}$ & - & - \\
\hline- & - & Polysiphonia sp. & C & - & - \\
\hline- & - & Rhodymenia australis & C & - & - \\
\hline- & - & R. palmate & C & - & - \\
\hline- & - & Scinaia indica & C & - & - \\
\hline- & - & S. furcellata & $R$ & - & - \\
\hline- & - & Sebdenia polydactyla & C & - & - \\
\hline- & - & Spyridia alternans & C & - & - \\
\hline- & - & Soleria robusta & C & - & - \\
\hline
\end{tabular}

Note: $\mathrm{C}=$ Common, $\mathrm{R}=$ Rare 
Table 6 Distribution of corals in the Gulf

\begin{tabular}{|c|c|c|c|c|c|c|c|c|c|c|c|c|c|c|c|}
\hline $\begin{array}{l}\text { Species/ } \\
\text { Location }\end{array}$ & MB I & MB2 & MB3 & MB4 & MB5 & MB6 & MB7 & MB8 & MB9 & MB I 0 & MB I I & MB I 2 & MB I 3 & MB I 4 & MB I5 \\
\hline $\begin{array}{l}\text { Esammocora } \\
\text { digitata }\end{array}$ & - & - & - & - & - & - & - & + & - & - & - & - & - & - & - \\
\hline Acropora humilis & - & - & + & + & - & - & + & + & - & - & - & - & - & - & - \\
\hline A.squamosa & - & - & - & + & - & - & - & - & - & - & - & - & - & - & - \\
\hline $\begin{array}{l}\text { Montipora } \\
\text { explanata }\end{array}$ & + & - & + & + & - & + & + & - & + & + & + & + & + & + & + \\
\hline M.venosa & - & - & - & + & - & - & + & - & - & - & - & - & - & - & - \\
\hline M.turgescons & - & - & - & - & - & - & + & - & - & - & - & - & - & - & - \\
\hline M.hispida & + & + & - & + & + & - & + & + & + & + & + & - & - & - & + \\
\hline M.foliosa & - & - & - & + & - & - & + & - & - & - & - & - & - & - & - \\
\hline M.monasteriata & - & - & - & + & - & - & + & - & - & - & - & - & - & - & - \\
\hline Coscinaraea monile & + & + & + & + & + & + & + & + & + & - & - & - & - & - & + \\
\hline Siderastrea & + & - & - & - & - & - & - & - & - & - & - & - & - & - & - \\
\hline $\begin{array}{l}\text { Pseudosiderastrea } \\
\text { tayami }\end{array}$ & + & - & - & - & - & - & + & + & + & + & + & + & + & + & + \\
\hline $\begin{array}{l}\text { Goniopora } \\
\text { planulata }\end{array}$ & + & + & - & - & + & + & + & - & + & + & - & + & - & - & + \\
\hline G.minor & - & - & - & + & - & - & + & - & - & - & - & - & - & - & + \\
\hline G.nigra & + & + & - & + & + & + & + & - & - & + & - & - & - & - & + \\
\hline Porites leutea & + & + & + & + & - & - & + & - & - & - & - & + & - & - & + \\
\hline P.lichen & + & - & - & - & - & - & + & - & + & - & - & + & - & + & + \\
\hline P.compressa & + & + & - & - & - & - & - & - & - & - & - & - & - & - & + \\
\hline Favia speciosa & - & - & - & - & - & - & - & - & - & - & - & - & - & - & + \\
\hline F.favus & + & + & + & + & + & + & + & + & + & + & + & + & + & + & + \\
\hline Favites complanata & + & + & + & + & + & + & + & - & - & + & - & - & - & + & + \\
\hline F. melicerus & + & - & + & - & - & - & - & - & + & - & - & - & - & + & + \\
\hline $\begin{array}{l}\text { Goniastrea } \\
\text { pectinata }\end{array}$ & + & + & + & + & + & + & + & - & + & + & + & - & + & + & + \\
\hline Platygyra sinensis & + & + & + & + & - & - & - & - & - & + & - & - & - & + & + \\
\hline Hydnophora exesa & + & + & + & + & - & - & - & - & - & + & - & - & + & - & + \\
\hline $\begin{array}{l}\text { Plesiastrea } \\
\text { versipora } \\
\text { Leptastrea }\end{array}$ & - & + & - & - & - & - & + & - & - & - & - & - & - & - & - \\
\hline purpurea & - & - & - & - & - & - & - & - & - & - & - & - & - & - & - \\
\hline Cyphastrea serailia & + & + & + & + & + & + & + & + & + & + & - & - & + & + & + \\
\hline Symphyllia radian & - & + & - & + & - & + & - & - & + & - & - & - & - & - & - \\
\hline $\begin{array}{l}\text { Acanthastrea } \\
\text { simplex } \\
\text { Mvcedium }\end{array}$ & + & + & + & + & - & - & - & - & + & + & - & - & - & - & + \\
\hline elephantotus & - & - & - & + & - & - & - & - & - & - & - & - & - & - & - \\
\hline Paracyathus stokesi & + & - & - & - & - & - & - & - & - & - & - & - & - & + & - \\
\hline Polycyathus verrilli & + & - & + & - & - & - & + & - & - & - & - & - & - & - & - \\
\hline Tubastraea aurea & + & + & + & + & + & - & - & - & + & + & - & - & - & - & - \\
\hline Turbinaria crater & + & + & - & + & - & - & + & - & - & - & - & - & - & - & + \\
\hline T.peltata & - & + & + & + & + & + & + & - & - & + & - & - & + & + & + \\
\hline
\end{tabular}




\section{Planktonic and Benthic Habitat}

Survey was conducted for the study of planktonic and benthic habitat Study of biological status of any water body play an important role in assessing the causes of impact on water body and quality of the water. Here the biological parameter considered during EB survey are primary productivity, phytoplankton count, pigment analysis, zooplankton count, availability of benthic organism, fish and other micro habitat (Table 5\&6).

In recent years, biodiversity of Marine Park/Marine Sanctuary has been under threat on several scores like extraction of corals and sands by cement industries, increased turbidity of water, oil refineries, chemical industries and mechanized fishing boats. Kumar et al., ${ }^{2}$ have reported 31 species of corals in the Marine National Park. There were two catastrophic and localized bleaching events happened in this region..$^{3-4}$ Coral bleaching and associated mortality not only have negative impacts on coral communities, but they also impact fish communities and the human communities that depend on coral reefs and associated fisheries for livelihoods and wellbeing. Bleached corals are likely to have reduced growth rates, decreased reproductive capacity, increased susceptibility to diseases and elevated mortality rates. Nearly everything in a coral-reef ecosystem depends on corals, or on the reef structure in some way. Coral colonies provide a source of food and shelter for countless reef-associated organisms and their health is of critical importance to the ecology of the reef community.

\section{Conclusion}

The area in question is rich in marine biodiversity especially Corals and some part of the Gulf has been protected under Marine National Park and Marine Sanctuary in 1980 under the provision of the Wildlife (Protection) Act, 1972 of India. There are many illegal fishing, fish trade, goods transport and many other activities reported from the area in question. The situation is going to worsen due to increase in ship transportation. There is an urgent need to implement the effective ecological management plan to restore the marine biodiversity of the Gulf of Kutch.

\section{Acknowledgements}

None.

\section{Conflict of interest}

Author declares that he has no conflict of interest.

\section{References}

1. Adhavan D, Kamboj RD, Marimuthu N, et al. Seasonal variation and climate change influence coral bleaching in Pirotan Island, Gulf of Kachchh Marine National Park, Gujarat. Curr Sci. 2014;107(11):17801781 .
2. Kumar JSY, Marimuthu N, Geetha S, et al. Longitudinal variations of coral reef features in the Marine National Park, Gulf of Kachchh. J Coast Conserv. 2014;18:167-175.

3. Adhavan D, Kamboj RD, Chavda DV, et al. Status of Intertidal Biodiversity of Narara Reef Marine National Park, Gulf of Kachchh, Gujarat. J Mar Biol Oceanogr. 2014;3:3.

4. Adhavan D, Marimuthu N, Tikadar S, et al. Impact of Algal Bloom on Mangroves and Coral Reef Ecosystemin Marine National Park, Gulf of Kachch, Gujarat, India. Journal of Marine Biology and Aquaculture. 2015;(2):1-2.

5. Rathoure Ashok K. Ecological status around Victor Port, Rajula Taluka, District Amreli in the State of Gujarat. Oct Jour Env Res. 2017;5(2):82105.

6. Vijaya Sankar R, Ravikumar R, M Ganesh Babu. On the collection of a Peninsular Endemic, Barleria stocksii (Acanthaceae), after a century. Zoo's Print. 2005;20:1820.

7. Vollenweider RA. A Manual of Methods For Measuring Primary Production in Aquatic Environment. IBP Handbook No. 12, Blackwell Scientific Publications. 1969.

8. Shendage SM, Yadav SR. Revision of the Genus Barleria (Acanthaceae) in India. Rheedea. 2010;20(2):81-230.

9. Misra R. Ecology Workbook. Scientific Publishers. 2013.

10. Lackey J.B. The manipulation and counting of river plankton and changes in some organisms due to formalin preservation. US Public Health Reports. 1938;53:2081-93.

11. Jain SK. The Problem of Endangered Species. Concepts, Problems and Solutions. In: Tropical Ecosystems: Ecolosv and Management. Singh KP, Singh JS, editors. New delhi: WIiley Eastern limited. 1992;69-80.

12. IUCN. Guidelines for Using the IUCN Red List Categories and Criteria, version 8.1 (August 2010), prepared by the Standards and Petitions Subcommittee of the IUCN Species Survival Commission. 2010.

13. Edmondson WT. A simplified method for counting phytoplankton. In: A manual on methods for measuring primary production in Aquatic environments. Vollenmeider RE, editors. Oxford: Balckwell Sci Pub; 1974.

14. Colebrook JM. Continuous Plankton records: Methods of Analysis, 1950-59. Bulletins of Marine Ecology. 1960;5:51-64.

15. Batten SD, Clarke R, Flinkman J. CPR Sampling: the technical background, material and methods, consistency and comparability. Progress in Oceanography. 2003;58:193-215.

16. APHA. Standard methods for the Examination of water and waste water. New York: American Public Health, Association; 1971.

17. Rathoure Ashok K. Terrestrial and Marine ecological status around Pindara Jetty in Devbhoomi Dwarka, Gujarat. Oct Jour Env Res. 2018;6(1):006-030a. 